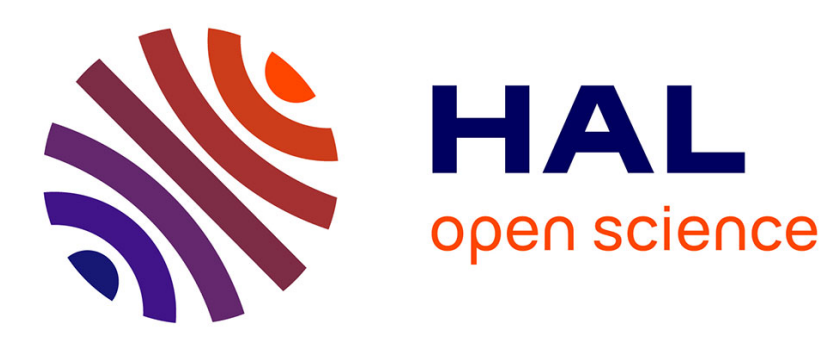

\title{
Redistribution of germanium during dynamic recrystallization of sphalerite
}

Alexandre Cugerone, Bénédicte Cenki-Tok, Emilien Oliot, Manuel Muñoz, Fabrice Barou, Vincent Motto-Ros, Elisabeth Le Goff

\section{- To cite this version:}

Alexandre Cugerone, Bénédicte Cenki-Tok, Emilien Oliot, Manuel Muñoz, Fabrice Barou, et al.. Redistribution of germanium during dynamic recrystallization of sphalerite. Geology, 2019, 48 (3), pp.236-241. 10.1130/G46791.1 . hal-03020920

\section{HAL Id: hal-03020920 https://hal.science/hal-03020920}

Submitted on 24 Nov 2020

HAL is a multi-disciplinary open access archive for the deposit and dissemination of scientific research documents, whether they are published or not. The documents may come from teaching and research institutions in France or abroad, or from public or private research centers.
L'archive ouverte pluridisciplinaire HAL, est destinée au dépôt et à la diffusion de documents scientifiques de niveau recherche, publiés ou non, émanant des établissements d'enseignement et de recherche français ou étrangers, des laboratoires publics ou privés. 
Publisher: GSA

Journal: GEOL: Geology

DOI:10.1130/G46791.1

https://doi.org/10.1130/G46791.1

Manuscript received 21 July 2019

Revised manuscript received 30 October 2019

Manuscript accepted 2 November 2019

*E-mail: alexandre.cugerone@umontpellier.fr

CITATION: Cugerone, A., et al., 2020, Redistribution of germanium during dynamic recrystallization of sphalerite: Geology, v. 48, p. XXX-XXX, https://doi.org/10.1130/G46791.1

Printed in USA

${ }^{1}$ GSA Data Repository item 2020062, Item DR1 (EPMA analytical conditions), Item DR2 (EDS Ge map of Figures 3A-3C), Item DR3 (corresponding EPMA analyses of the Figure 4D), and Item DR4 (transmitted plane polarized light microphotograph and EDS Ge map of Figures $4 \mathrm{~A}-4 \mathrm{C})$, is available online at http://www.geosociety.org/datarepository/2020/, or on request from editing@geosociety.org.

\title{
Redistribution of germanium during dynamic
}

\section{recrystallization of sphalerite}

\author{
Alexandre Cugerone ${ }^{1 *}$, Bénédicte Cenki-Tok ${ }^{1,2},{\text { Emilien } \text { Oliot }^{1} \text {, Manuel Muñoz }}^{1}$, \\ Fabrice Barou ${ }^{1}$, Vincent Motto-Ros ${ }^{3}$, and Elisabeth Le Goff ${ }^{4}$ \\ ${ }^{1}$ Géosciences Montpellier, Université de Montpellier, CNRS, 34095 Montpellier cedex 5, \\ France \\ ${ }^{2}$ Earthbyte Research Group, School of Geosciences, University of Sydney, Sydney, NSW \\ 2006, Australia \\ ${ }^{3}$ Institut Lumière Matière, Université Lyon 1, CNRS, 69622 Villeurbanne, France \\ ${ }^{4}$ Bureau de Recherches Géologiques et Minières (BRGM), 34000 Montpellier, France
}

\section{ABSTRACT}


Publisher: GSA

Journal: GEOL: Geology

DOI: $10.1130 / \mathrm{G} 46791.1$

Rare metals are essential to the development of the "green" technologies that are at the core of low-carbon societies. In nature, these metals are frequently present in trace amounts scattered in base metal ore deposits, but the physico-chemical processes that are responsible for their concentration into strategic minerals are still poorly understood.

Based on laser-induced breakdown spectroscopy (LIBS), coupled with electron backscattered diffraction (EBSD) analysis, this study shows that plastic deformation and subsequent syntectonic recrystallization of sphalerite (zinc sulfide, $\mathrm{ZnS}$ ) led to the spatial redistribution of germanium $(\mathrm{Ge})$ : from a background level of a few hundreds of parts per million in undeformed primary sphalerite to tens of weight-percent in neocrystallized Ge minerals. During dynamic recrystallization, Ge is likely released from the crystal lattice of parent sphalerite and subsequently concentrated in Ge minerals, leaving behind a Gedepleted, recrystallized sphalerite matrix. Identifying how rare metals concentrate through deformation and syntectonic recrystallization at the mineral scale is essential to understand the spatial redistribution and localization at the deposit scale. This study highlights the importance of coupling in situ chemical mapping analysis with macro- and microstructural characterization when targeting rare metals in deformed ore.

\section{INTRODUCTION}

Many rare metals are critical to the sustained development of $21^{\text {st }}$ century technologies; for example, germanium (Ge) is essential to optic-fiber systems used in military and civil telecommunications. The production of rare metals remains challenging, notably because only a few percent of the total rare metal content is recovered from base metal deposits (Ruiz et al., 2018; U.S. Geological Survey, 2019). In this study, we focused on natural processes leading to the spatial redistribution of Ge, a 
Publisher: GSA

Journal: GEOL: Geology

DOI:10.1130/G46791.1

rare metal for which the background concentration level in the continental crust does not exceed 1.5 ppm (Smith and Huyck, 1999). Redistribution of rare metals during metamorphism and deformation of base metal sulfides may be overlooked by standard mineral exploration approaches. Understanding the redistribution of rare metals that form their own high-grade minerals will lead to a better availability of these elements during ore processing, as well as enhanced extraction and recovery efficiencies. In nature, Ge is associated with sphalerite (zinc sulfide, $\mathrm{ZnS}$ ) deposits and coal seams at concentrations of a few thousand parts per million (Höll et al., 2007; Frenzel et al., 2014, 2016).

Germanium is generally recovered through pyro- and hydro-metallurgical bulk ore processing (Moskalyk 2004). In some lead, zinc, and copper deposits, small $(<100 \mu \mathrm{m})$ accessory Ge minerals that can contain up to $70 \mathrm{wt} \%$ Ge are locally described, testifying to Ge remobilization and/or concentration at the deposit scale (Johan et al., 1983; Bernstein, 1985; Melcher et al., 2006; Horn et al., 2018). These Ge minerals are found in a large variety of deposits, such as Kipushi-type (breccia-pipe), orogenic veins, volcanichosted massive sulfide (VHMS), or epithermal deposits (Ottemann and Number, 1972; Intiomale and Oosterbosch, 1974; Wagner and Monecke, 2005; Belissont et al., 2019), and in Neoproterozoic to Variscan age host rocks (Johan et al., 1983; Melcher et al., 2006; Horn et al., 2018). In addition, Ge minerals typically occur in hydrothermal systems hosted in low-grade metamorphic rocks (Cugerone et al., 2018a). Nevertheless, the physico-chemical mechanisms that induce the remobilization of $\mathrm{Ge}$ in sulfide ores are not sufficiently understood, and, consequently, the economic potential of this rare metal occurrence remains difficult to assess. 
Publisher: GSA

Journal: GEOL: Geology

DOI:10.1130/G46791.1

In the past two decades, numerous studies have shown that trace-element

distribution in deformed sulfides may be closely related to microstructures (e.g., in pyrite, pyrrhotite, löllingite-arsenopyrite; Tomkins and Mavrogenes, 2001; Cook et al., 2009a; Vukmanovic et al., 2014). Here, we propose an innovative approach combining (1) electron backscattered diffraction (EBSD), (2) laser-induced breakdown spectroscopy (LIBS), and (3) in situ electron probe microanalyzer (EPMA) measurements to illustrate the relationships between Ge distribution and sphalerite microstructure. In naturally deformed sphalerite from the Arre Pb-Zn deposit in the Pyrenean Axial Zone (PAZ), Pyrenees, brunogeierite $\left(\mathrm{GeFe}_{2} \mathrm{O}_{4}\right)$ and carboirite $\left[\mathrm{GeFeAl}_{2} \mathrm{O}_{5}(\mathrm{OH})_{2}\right]$ have already been described (Laforet et al., 1981; Oudin, 1982; Johan et al., 1983; Johan and Oudin, 1986). Therefore, this ore deposit is a first-order target to decipher the links between sphalerite deformation and Ge remobilization.

\section{GEOLOGICAL SETTING AND SAMPLES}

The study area is located in the Paleozoic basement of the PAZ, where numerous $\mathrm{Pb}-\mathrm{Zn}$ deposits have been exploited in the $20^{\text {th }}$ century (Fig. 1A). Following Denèle et al. (2014), we documented three Variscan deformation stages $\left(D_{1}\right.$ to $\left.D_{3}\right)$. A poorly expressed $\mathrm{S}_{1}$ foliation is associated with regional $\mathrm{D}_{1}$ deformation and medium-pressure and lowtemperature $\mathrm{M}_{1}$ metamorphism. A well-expressed but local $\mathrm{S}_{2}$ cleavage is subvertical and is related to a late Variscan $\mathrm{D}_{2}$ deformation stage, characterized by a low-pressure and medium-temperature $\mathrm{M}_{2}$ metamorphism (Mezger and Passchier, 2003). Finally, a very late Variscan or Pyrenean $\mathrm{D}_{3}$ deformation occurs as localized shear zones and faults (Mezger et al., 2012; Carreras and Druguet, 2014; Cochelin et al., 2017). 
Publisher: GSA

Journal: GEOL: Geology

DOI:10.1130/G46791.1

Three types of $\mathrm{Pb}-\mathrm{Zn}$ occurrences are recognized by Cugerone et al. (2018b): type

1, type $2 \mathrm{a}$, and type $2 \mathrm{~b}$. This study focuses on the Arre locality (Fig. 1B), where epigenetic type $2 \mathrm{~b}$ veins have been reported (Reyx, 1973). Three subvertical sphalerite veins, striking $\mathrm{N} 060^{\circ} \mathrm{E}$ to $\mathrm{N} 080^{\circ} \mathrm{E}$, are embedded in Lower-Devonian host marble and calc-schist. These veins are structurally located in the hinge zone of a kilometer-scale $\mathrm{F}_{2}$ anticline and are parallel to the local $\mathrm{S}_{2}$ cleavage (Figs. 1C and 2A).

The sphalerite occurrence was sampled in the westernmost part of the Arre locality (Fig. 1C). These decimetric veins crosscut $\mathrm{S}_{0}-\mathrm{S}_{1}$ structures (Fig. 2A) and are essentially composed of brownish sphalerite ( $\sim 80 \mathrm{vol} \%$; Fig. $2 \mathrm{~B})$ with minor chalcopyrite, pyrite, galena, graphite, and muscovite in a gangue of cockade quartz, carbonate, and rare barite (Fig. 2C).

\section{METHODS}

EPMA was carried out using a Cameca SX100 at Géosciences Montpellier (Montpellier, France) following the methodology outlined by Cugerone et al. (2018a). Ge and $\mathrm{Cu}$ were analyzed using two large lithiumfluoride (LLIF) monochromators. Detection limits calculated by internal Cameca procedures (PeakSight program (https://www.cameca.com/service/software/peaksight) in the SX100 software, using $1 \sigma$ error) were $85 \mathrm{ppm}$ and $123 \mathrm{ppm}$ for Ge and $\mathrm{Cu}$, respectively (Item DR1 in the GSA Data Repository $\left.{ }^{1}\right)$.

Simultaneous energy-dispersive spectrometry (EDS) and EBSD mapping were acquired with a Camscan Crystal Probe X500FE scanning electron microscope at the University of Montpellier (France). Operating conditions were $20 \mathrm{kV}$ and $5 \mathrm{nA}$ with a working distance of $25 \mathrm{~mm}$ under $2 \mathrm{~Pa}$ low vacuum and a step size of $5 \mu \mathrm{m}$. Data were 
Publisher: GSA

Journal: GEOL: Geology

DOI:10.1130/G46791.1

processed with the Oxford Instruments AZtec and Channel 5 software

(https://nano.oxinst.com/products/ebsd/post-processing-software).

LIBS multi-elemental imaging was performed at the Institute Lumière Matière, University of Lyon 1 (France); this all-optical analytical technique was used to map the distribution of Ge in sphalerite (Cáceres et al., 2017; Fabre et al., 2018). The sample was analyzed using a Nd:YAG laser with a pulse energy of $600 \mu \mathrm{J}$ operating at $100 \mathrm{~Hz}$ and a lateral resolution of $13 \mu \mathrm{m}$. The spectrometer was configured to detect an intense line of Ge located at $265.1 \mathrm{~nm}$. The resulting detection limit was $10 \mathrm{ppm}$.

\section{RESULTS}

\section{Sphalerite Microstructures and Locations of Ge Minerals}

The vein is dominated by sphalerite associated with quartz (Figs. 2B and 2C). Sphalerite appears intensely zoned with brownish tint variations in transmitted light microscopy (Figs. 2C and 3A). The sphalerite grain size is highly heterogeneous (from $<10 \mu \mathrm{m}$ to $>1 \mathrm{~mm}$ ) and distributed in two distinct populations (Figs. 3B and 4C): The threshold between coarse- and fine-grained size was fixed at $100 \mu \mathrm{m}$ (Fig. 3D). Combining the EBSD grain size map and optical observations, three grain types could be distinguished: coarse millimeter-size grains with (1) dark or (2) light-brownish domains, and (3) small $(<100 \mu \mathrm{m})$ light-brownish grains. Microstructures in twinned primary sphalerite were mostly internal crystalline strain expressed through deformation bands and lamellae (Figs. 3C and 4A). In a single parent grain, the cumulative internal misorientation could reach a value of $22^{\circ}$ (Fig. 3E).

Small sphalerite grains formed aggregates that pervasively mantled and/or crosscut coarse primary sphalerite (Figs. 3C, 3E, and 4A). The misorientation angle 
Publisher: GSA

Journal: GEOL: Geology

DOI:10.1130/G46791.1

distribution of neighbor pairs revealed a dominance of low values (from $2^{\circ}$ to $6^{\circ}$; Fig. $3 F)$, four times higher than the $45^{\circ}$ peak of uncorrelated pairs, which followed the predicted random distribution. At thin section scale, fine-grained aggregates outlined the $\mathrm{S}_{2}$ cleavage (Figs. 3 and 4), and in coarse primary sphalerite, narrow bands composed of small grains were frequently parallel to twins (Figs. 3C and 4A).

The EDS chemical map acquired in this area (Item DR2) indicates that Ge was locally hyperconcentrated in micrometric Ge minerals (reported as yellow dots in Fig. 3B), located mostly in the fine-grained sphalerite aggregates.

\section{Ge Partitioning in Sphalerite}

Germanium concentration was mapped in relation to sphalerite texture in a monomineralic layer of fine-grained sphalerite that crosscut an aggregate of large, twinned primary grains (Figs. 4A-4C). The distribution of Ge cations in sphalerite at the thin section scale was highly heterogeneous (Fig. 4B) and mimicked the patchy brownish domains visible in optical microscopy (Item DR4). The most Ge-depleted zones in sphalerite (i.e., blue areas in Fig. 4B) corresponded to both the fine-grained population and random parts of light primary sphalerite (Figs. 4A and 4B). Intermediate Ge concentrations in sphalerite matched the dark part of coarse grains (i.e., brown tints in Fig. 4B). The limit between Ge-rich (dark) and Ge-depleted (light) sphalerite domains was generally progressive and diffuse (Fig. 4B). Zones displaying higher Ge contents (i.e., $>15 \mathrm{wt} \% \mathrm{Ge}$; yellow areas in Fig. 4B) clearly indicated the presence of Ge minerals (brunogeierite; see inset in Fig. 4C). These were located in twinned, coarse primary grains, and in the fine-grained monomineralic layers that outlined the $\mathrm{S}_{2}$ cleavage (Figs. 4A-4C; Item DR4). 
Publisher: GSA

Journal: GEOL: Geology

DOI:10.1130/G46791.1

$\mathrm{Ge}$ and $\mathrm{Cu}$ contents have been measured in the three sphalerite textures from several vein-type deposits in the PAZ (including the studied Arre deposit; Fig. 4D; Item DR3). The lowest Ge concentrations in sphalerite are below $\sim 150 \mathrm{ppm} \mathrm{Ge}$ and are found in light fine-grained aggregates and light domains in coarse primary sphalerite. Dark domains in coarse primary grains display intermediate Ge concentrations from $\sim 150$ to $\sim 650 \mathrm{ppm}$ Ge.

\section{INTERPRETATION AND DISCUSSION}

\section{Deformation and Dynamic Recrystallization of Sphalerite}

The Arre vein displays evidence of strain superimposition, which was verified at the sample scale by a subvertical $\mathrm{S}_{2}$ cleavage. Strain in sphalerite is primarily accommodated by internal crystalline plasticity forming deformation bands and lamellae (Figs. 3C and 3E). This process indicates active dislocation creep mechanisms in the $\mathrm{ZnS}$ (Kollenberg and Siemes, 1983; Hirth and Tullis, 1992). By comparison with experimental deformation in sphalerite (Siemes and Borges, 1979) and deformation mechanisms in pyrite that support a brittle-ductile transition zone as low as $200-260{ }^{\circ} \mathrm{C}$ at geological strain rates (Barrie et al., 2011), dynamic recrystallization of sphalerite may occur at lower temperature even if no deformation map is yet available to confirm these conditions.

The textures show coarse sphalerite grains mantled by small grains $(<100 \mu \mathrm{m}$; Figs. 3B and 3D), or cut through by $\mathrm{S}_{2}$-parallel zones of fine-grained sphalerite. Twins in parent sphalerite often act as inherited structural heterogeneity during deformation (Couderc et al., 1985), inducing the formation of narrow bands of small, aggregated grains (Figs. 3C and 4A). These observations point to syntectonic grain-size reduction, 
Publisher: GSA

Journal: GEOL: Geology

DOI:10.1130/G46791.1

deriving from dynamic recrystallization. Indeed, small recrystallized grains develop at the expense of large parent grains (Figs. $3 \mathrm{C}$ and $4 \mathrm{~A}$ ). With the rising strain and the increase of internal misorientations within parent grains (beyond $20^{\circ}$; Fig. 3E), the high density of low misorientation angles between neighbor pairs (Fig. 3F) suggests that strain-induced subgrain rotation recrystallization was the main deformation mechanism for sphalerite recrystallization (e.g., Guillope and Poirier, 1979).

\section{Mechanisms for Internal Ge Remobilization}

Sphalerite integrates tetravalent $\mathrm{Ge}$ involving monovalent $\mathrm{Cu}$ in a coupled substitution mechanism (Belissont et al., 2016). Germanium generally occurs in relatively low concentrations (up to a few thousands of parts per million), often associated with coarse parent sphalerite grains that display Ge-rich (dark) and Ge-depleted (light) domains (Cook et al., 2009b; Belissont et al., 2014; Bauer et al., 2018). Here, we show that deformation at low- to medium-grade $\left(<400{ }^{\circ} \mathrm{C}\right)$ conditions leads to dynamic sphalerite recrystallization, inducing Ge partitioning between recrystallized Ge-depleted sphalerite and newly crystallized Ge minerals. Although Ge is not homogeneously distributed in parent sphalerite (i.e., rich-dark vs. depleted-light domains), Ge displays higher pervasive concentration in dark coarse grains (up to $\sim 650 \mathrm{ppm}$ ) compared to light recrystallized domains ( $<100 \mathrm{ppm}$ ), in which Ge minerals frequently occur (Figs. 3B, 4B, and 4C). We propose that Ge cations were internally remobilized from the parent sphalerite lattice during intracrystalline deformation, most likely via solid-state mechanical transfer (dislocation flow; Marshall and Gilligan, 1993), as a result of increasing internal strain and subsequent recovery. During dynamic recrystallization and $\mathrm{S}_{2}$ cleavage development, a probable fluid-assisted solution transfer (solution- 
Publisher: GSA

Journal: GEOL: Geology

DOI: $10.1130 / \mathrm{G} 46791.1$

precipitation creep) allowed Ge to be remobilized and promoted the neocrystallization of Ge minerals (essentially oxides or chloritoids; Fig. 4C; Johan et al., 1983; Cugerone et al., 2018a). Germanium from an external fluid source is not needed to crystallize the newly formed Ge minerals.

\section{Rare Element Redistribution in Other World-Class Deposits}

Germanium minerals and Ge chemical heterogeneity are reported from other deformed sulfide occurrences. For example, Kipushi-type deposits (Melcher et al., 2006; Horn et al., 2018), volcanic-hosted massive sulfide deposits (Reiser et al., 2011), and deformed carbonate-hosted deposits in China (Huize, Niujiaotang deposits; Ye et al., 2011) and in Brazil (Monteiro et al., 2006) show recrystallized Ge-rich sphalerite ore. In other chemical systems, formation of the indium-bearing mineral roquesite $\left(\mathrm{CuInS}_{2}\right)$ hosted in bornite $\left(\mathrm{Cu}_{5} \mathrm{FeS}_{4}\right)$ may be attributed to indium remobilization and diffusion from In-rich sphalerite under metamorphic conditions (Jonsson et al., 2013). Coupling microstructural and in situ chemical analysis of deformed sulfides is key to exploring potential rare metal-rich deposits in orogens.

\section{CONCLUSIONS}

Multiscale textural and chemical observations show that the Arre vein-type zinc sulfide deposit has undergone deformation that promoted dynamic recrystallization of sphalerite, inducing Ge remobilization and subsequent concentration in Ge minerals. This mechanism, assisted by hydrothermal fluids, led to the development of a fine-grained Gedepleted sphalerite matrix, in which Ge minerals crystallized. Numerous analogues to the Arre epigenetic sphalerite exist in world-class $\mathrm{Pb}-\mathrm{Zn}$ deposits, and coupling textural and 
Publisher: GSA

Journal: GEOL: Geology

DOI:10.1130/G46791.1

microstructural observations with trace-element chemical mapping may be, in the future, a key improvement to help understand the natural occurrence of rare metals.

\section{ACKNOWLEDGMENTS}

This study was funded by the French national program "Référentiel Géologique de France" (RGF-Pyrénées) of the French Geological Survey (Bureau de Recherches Géologiques et Minières; BRGM), and through the Centre National de la Recherche Scientifique Institut National des Sciences de l'Univers (INSU) Tellus Connaissance et Technologie du Sous-Sol pour son Exploitation et Usage Durable (CESSUR) program. Cenki-Tok acknowledges funding from the European Union's Horizon 2020 research and innovation program under grant agreement 793978 . We gratefully acknowledge C.

Nevado and D. Delmas for the exceptional thin section preparation and B. Boyer for his involvement in electron probe microanalysis (EPMA). We are thankful to Mark Quigley for editorial handling and to Alan Boyle, Jochen Kolb, David Huston, and two anonymous reviewers for highly constructive comments.

\section{REFERENCES CITED}

Barrie, C.D., Pearce, M.A., and Boyle, A.P., 2011, Reconstructing the pyrite deformation mechanism map: Ore Geology Reviews, v. 39, p. 265-276, https://doi.org/10.1016/j.oregeorev.2011.03.006.

Bauer, M.E., Burisch, M., Ostendorf, J., Krause, J., Frenzel, M., Seifert, T., and Gutzmer, J., 2018, Trace element geochemistry of sphalerite in contrasting hydrothermal fluid systems of the Freiberg district, Germany: Insights from LA-ICP-MS analysis, nearinfrared light microthermometry of sphalerite-hosted fluid inclusions, and sulfur 
Publisher: GSA

Journal: GEOL: Geology

DOI:10.1130/G46791.1

isotope geochemistry: Mineralium Deposita, v. 54, p. 237-262,

https://doi.org/10.1007/s00126-018-0850-0.

Belissont, R., Boiron, M.C., Luais, B., and Cathelineau, M., 2014, LA-ICP-MS analyses

of minor and trace elements and bulk Ge isotopes in zoned Ge-rich sphalerites from the Noailhac-Saint-Salvy deposit (France): Insights into incorporation mechanisms and ore deposition processes: Geochimica et Cosmochimica Acta, v. 126, p. 518540, https://doi.org/10.1016/j.gca.2013.10.052.

Belissont, R., Munoz, M., Boiron, M.C., Luais, B., and Mathon, O., 2016, Distribution and oxidation state of $\mathrm{Ge}, \mathrm{Cu}$ and $\mathrm{Fe}$ in sphalerite by $\mu$-XRF and $\mathrm{K}$-edge $\mu$-XANES: Insights into Ge incorporation, partitioning and isotopic fractionation: Geochimica et Cosmochimica Acta, v. 177, p. 298-314, https://doi.org/10.1016/j.gca.2016.01.001.

Belissont, R., Munoz, M., Boiron, M., Luais, B., and Mathon, O., 2019, Germanium crystal chemistry in Cu-bearing sulfides from micro-XRF mapping and micro-Xanes spectroscopy: Minerals (Basel), v. 9, p. 1-12, https://doi.org/10.3390/min9040227.

Bernstein, L.R., 1985, Germanium geochemistry and mineralogy: Geochimica et Cosmochimica Acta, v. 49, p. 2409-2422, https://doi.org/10.1016/00167037(85)90241-8.

Cáceres, J.O., Pelascini, F., Motto-Ros, V., Moncayo, S., Trichard, F., Panczer, G., Marín-Roldán, A., Cruz, J.A., Coronado, I., and Martín-Chivelet, J., 2017, Megapixel multi-elemental imaging by laser-induced breakdown spectroscopy: A technology with considerable potential for paleoclimate studies: Scientific Reports, v. 7, p. 1-11, https://doi.org/10.1038/s41598-017-05437-3. 
Publisher: GSA

Journal: GEOL: Geology

DOI:10.1130/G46791.1

Carreras, J., and Druguet, E., 2014, Framing the tectonic regime of the NE Iberian

Variscan segment, in Schulmann, K., et al., eds., The Variscan Orogeny: Extent, Timescale and the Formation of the European Crust: Geological Society [London]

Special Publication 405, p. 249-264, https://doi.org/10.1144/SP405.7.

Cochelin, B., Lemirre, B., Denèle, Y., De Saint Blanquat, M., Lahfid, A., and Duchêne, S., 2017, Structural inheritance in the Central Pyrenees: The Variscan to Alpine tectonometamorphic evolution of the Axial Zone: Journal of the Geological Society [London], v. 175, p. 336-351, https://doi.org/10.1144/jgs2017-06ㅁ.

Cook, N.J., Ciobanu, C.L., and Mao, J., 2009a, Textural control on gold distribution in As-free pyrite from the Dongping, Huangtuliang and Hougou gold deposits, North China craton: Chemical Geology, v. 264, p. 101-121, https://doi.org/10.1016/j.chemgeo.2009.02.020.

Cook, N.J., Ciobanu, C.L., Pring, A., Skinner, W., Shimizu, M., Danyushevsky, L., SainiEidukat, B., and Melcher, F., 2009b, Trace and minor elements in sphalerite: A LAICPMS study: Geochimica et Cosmochimica Acta, v. 73, p. 4761-4791, https://doi.org/10.1016/j.gca.2009.05.045.

Couderc, J.J., Dudouit, I., Hennig-M ichaeli , C., and Levade, C., 1985, The interaction between slip and twinning systems in natural sphalerite experimentally deformed:

Physica Status Solidi, v. 90, p. 581-593, https://doi.org/10.1002/pssa.2210900222.

Cugerone, A., Cenki-Tok, B., Chauvet, A., Le Goff, E., Bailly, L., Alard, O., and Allard, M., 2018a, Relationships between the occurrence of accessory Ge-minerals and sphalerite in Variscan $\mathrm{Pb}-\mathrm{Zn}$ deposits of the Bossost anticlinorium, French Pyrenean 
Publisher: GSA

Journal: GEOL: Geology

DOI:10.1130/G46791.1

Axial Zone: Chemistry, microstructures and ore-deposit setting: Ore Geology

Reviews, v. 95, p. 1-19, https://doi.org/10.1016/j.oregeorev.2018.02.016.

Cugerone, A., Oliot, E., Chauvet, A., Gavalda, J., and Le Goff, E., 2018b, Structural

control on the formation of $\mathrm{Pb}-\mathrm{Zn}$ deposits: An example from the Pyrenean Axial

Zone: Minerals (Basel), v. 8, p. 1-20, https://doi.org/10.3390/min8110489.

Denèle, Y., Laumonier, B., Paquette, J.-L., Olivier, P., Gleizes, G., and Barbey, P., 2014, Timing of granite emplacement, crustal flow and gneiss dome formation in the Variscan segment of the Pyrenees, in Schulmann, K., et al., eds., The Variscan Orogeny: Extent, Timescale and the Formation of the European Crust: Geological Society [London] Special Publication 405, p. 265-287, https://doi.org/10.1144/SP405.5.

Fabre, C., Devismes, D., Moncayo, S., Pelascini, F., Trichard, F., Lecomte, A., Bousquet, B., Cauzid, J., and Motto-Ros, V., 2018, Elemental imaging by laser-induced breakdown spectroscopy for the geological characterization of minerals: Journal of Analytical Atomic Spectrometry, p. 1-9, https://doi.org/10.1039/c8ja00048d.

Frenzel, M., Ketris, M.P., and Gutzmer, J., 2014, On the geological availability of germanium: Mineralium Deposita, v. 49, p. 471-486, https://doi.org/10.1007/s00126-013-0506-z.

Frenzel, M., Hirsch, T., and Gutzmer, J., 2016, Gallium, germanium, indium, and other trace and minor elements in sphalerite as a function of deposit type-A metaanalysis: Ore Geology Reviews, v. 76, p. 52-78, https://doi.org/10.1016/j.oregeorev.2015.12.017. 
Publisher: GSA

Journal: GEOL: Geology

DOI: $10.1130 / \mathrm{G} 46791.1$

Guillope, M., and Poirier, J.P., 1979, Dynamic recrystallization during creep of singlecrystalline halite: An experimental study: Journal of Geophysical Research, v. 84, p. 5557-5567, https://doi.org/10.1029/JB084iB10p05557.

Hirth, G., and Tullis, J., 1992, Dislocation creep regimes in quartz aggregates: Journal of Structural Geology, v. 14, p. 145-159, https://doi.org/10.1016/0191-8141(92)90053$\underline{\mathrm{Y}}$.

Höll, R., Kling, M., and Schroll, E., 2007, Metallogenesis of germanium—A review: Ore Geology Reviews, v. 30, p. 145-180, https://doi.org/10.1016/j.oregeorev.2005.07.034.

Horn, S., Dziggel, A., Kolb, J., and Sindern, S., 2018, Textural characteristics and trace element distribution in carbonate-hosted $\mathrm{Zn}-\mathrm{Pb}-\mathrm{Ag}$ ores at the Paleoproterozoic Black Angel deposit, central West Greenland: Mineralium Deposita, v. 54, p. 507524, https://doi.org/10.1007/s00126-018-0821-5.

Intiomale, M.M., and Oosterbosch, R., 1974, Géologie et géochimie du gisement de Kipushi, Zaïre, in Bartholomé P., ed., Gisements Stratiformes et Provinces Cupriferes: Liège, Centenaire Société Géologique de Belgique, p. 123164, https://popups.uliege.be:443/0037-9395/index.php?id=3472.

Johan, Z., and Oudin, E., 1986, Présence de grenats, $\mathrm{Ca}_{3} \mathrm{Ga}\left(\mathrm{GeO}_{4}\right)_{3}, \mathrm{Ca}_{3} \mathrm{Al}_{2}\left[(\mathrm{Ge}, \mathrm{Si}) \mathrm{O}_{4}\right]_{3}$ et d'un équivalent ferrifere, germanifere et gallifere de la sapphirine, $\mathrm{Fe}_{4}(\mathrm{Ga}, \mathrm{Sn}, \mathrm{Fe})_{4}$ $(\mathrm{Ga}, \mathrm{Ge})_{6} \mathrm{O}_{20}$, dans la blende des gisements de la zone axiale pyrénéenne. Conditions de formation des: Comptes Rendus de 'Académie des Sciences Paris, v. 9, p. 811816. 
Publisher: GSA

Journal: GEOL: Geology

DOI:10.1130/G46791.1

Johan, Z., Oudin, E., and Picot, P., 1983, Analogues germanifères et gallifères des silicates et oxydes dans les gisements de zinc des Pyrénées centrales, France: Argutite et carboirite, deux nouvelles espèces minérales: Tschermaks Mineralogische und Petrographische Mitteilungen, v. 31, p. 97-119, https://doi.org/10.1007/BF01084764.

Jonsson, E., Högdahl, K., Majka, J., and Lindeberg, T., 2013, Roquesite and associated indium-bearing sulfides from a Paleoproterozoic carbonate-hosted mineralization: Lindbom's prospect, Bergslagen, Sweden: Canadian Mineralogist, v. 51, p. 629-641, https://doi.org/10.3749/canmin.51.4.629.

Kollenberg, W., and Siemes, H., 1983, Experimental deformation of sphalerite-garnet ore under a confining pressure of $300 \mathrm{MPa}$ and at temperatures between $250^{\circ} \mathrm{C}$ and $300^{\circ}$ C, in Bilde-Sørensen, J.B., et al., eds., Deformation of Multi-Phase and Particle Containing Materials: Roskilde, Denmark, Risø National Laboratory, p. 351-356.

Laforet, C., Oudin, E., Picot, P., Pierrot, R., and Pillard, F., 1981, Métallogénie Régionale: Utilisation des Paragenèses Minéralogiques et des Minéraux Traceurs: Bureau de Recherches Geologiques et Minieres Rapport 80, SGN-175, 33 p., http://infoterre.brgm.fr/rapports/80-SGN-175-MGA.pdf.

Marshall, B., and Gilligan, L.B., 1993, Remobilization, syn-tectonic processes and massive sulphide deposits: Ore Geology Reviews, v. 8, p. 39-64, https://doi.org/10.1016/0169-1368(93)90027-V.

Melcher, F., Oberthür, T., and Rammlmair, D., 2006, Geochemical and mineralogical distribution of germanium in the Khusib Springs $\mathrm{Cu}-\mathrm{Zn}-\mathrm{Pb}-\mathrm{Ag}$ sulfide deposit, Otavi 
Publisher: GSA

Journal: GEOL: Geology

DOI:10.1130/G46791.1

Mountain Land, Namibia: Ore Geology Reviews, v. 28, p. 32-56,

https://doi.org/10.1016/j.oregeorev.2005.04.006.

Mezger, J.E., and Passchier, C.W., 2003, Polymetamorphism and ductile deformation of staurolite-cordierite schist of the Bossòst dome: Indication for Variscan extension in the Axial Zone of the central Pyrenees: Geological Magazine, v. 140, p. 595-612, https://doi.org/10.1017/S0016756803008112.

Mezger, J.E., Schnapperelle, S., and Rölke, C., 2012, Evolution of the Central Pyrenean Mérens fault controlled by near collision of two gneiss domes: Hallesches Jahrbuch für Geowissenschaften, v. 34, p. 11-30.

Monteiro, S.L.V., Bettencourt, S.J., Juliani, C., and de Oliveira, T.F., 2006, Geology, petrography, and mineral chemistry of the Vazante non-sulfide and Ambrosia and Fagundes sulfide-rich carbonate-hosted $\mathrm{Zn}-(\mathrm{Pb})$ deposits, Minas Gerais, Brazil: Ore Geology Reviews, v. 28, p. 201-234, https://doi.org/10.1016/j.oregeorev.2005.03.005.

Moskalyk, R.R., 2004, Review of germanium processing worldwide: Minerals Engineering, v. 17, p. 393-402, https://doi.org/10.1016/j.mineng.2003.11.014.

Ottemann, V.J., Nuber, B., 1972, Brunogeierit, ein Germanium-Ferritspinell: Neues Jahrbuch für Mineralogie, Monatshefte, p. 263-267.

Oudin, E., 1982, Minéralogie des Pyrénées Centrales: Bureau de Recherches Geologiques et Minieres Rapport 82, SGN-189 MGA, 38 p., http://infoterre.brgm.fr/rapports/82SGN-189-MGA.pdf. 
Publisher: GSA

Journal: GEOL: Geology

DOI:10.1130/G46791.1

Pouit, G., 1985, Les minéralisations Zn (Pb) Ba du Paléozoïque des Pyrénées Centrales: Une Mise au Point et un Compte Rendu des Missions 1984: Bureau de Recherches Geologiques et Minieres Rapport 85, DAM-037 GMX, 72 p.

Reiser, F.K.M., Rosa, D.R.N., Pinto, Ã.M.M., Carvalho, J.R.S., Matos, J.X., Guimaraes, F.M.G., Alves, L.C., and de Oliveira, D.P.S., 2011, Mineralogy and geochemistry of tin- and germanium-bearing copper ore, Barrigao re-mobilized vein deposit, Iberian Pyrite Belt, Portugal: International Geology Review, v. 53, p. 1212-1238, https://doi.org/10.1080/00206811003683168.

Reyx, J., 1973, Relations entre Tectonique, Métamorphisme de Contact et Concentrations Metalliques dans le Secteur des Anciennes Mines d'Arre et Anglas (HautesPyrénées-Pyrénées Atlantiques) [Ph.D. thesis]: Paris, France, University of Paris VI, $83 \mathrm{p}$.

Ruiz, A.G., Sola, P.C., and Palmerola, N.M., 2018, Germanium: Current and novel recovery processes, in Lee, S., ed., Advanced Material and Device Applications with Germanium: London, IntechOpen Limited, p. 9-29. https://doi.org/10.5772/INTECHOPEN.77997.

Siemes, H., and Borges, B., 1979, Experimental deformation of sphalerite single crystals under confining pressures of 3000 and 5000 bars at temperatures between $25^{\circ} \mathrm{C}$ and $450^{\circ} \mathrm{C}$ : Neues Jahrbuch für Mineralogie, v. 134, p. 288-304.

Smith, K.S., and Huyck, H.L.O., 1999, An overview of the abundance, relative mobility, bioavailability, and human toxicity of metals, in Plumlee, G.S., and Logsdon, M.J., eds., The Environmental Geochemistry of Mineral Deposits: Reviews in Economic Geology, v. 6A, p. 29-70. 
Publisher: GSA

Journal: GEOL: Geology

DOI:10.1130/G46791.1

Tomkins, A.G., and Mavrogenes, J.A., 2001, Redistribution of gold within arsenopyrite and löllingite during pro- and retrograde metamorphism: Application to timing of mineralization: Economic Geology and the Bulletin of the Society of Economic Geologists, v. 96, p. 525-534, https://doi.org/10.2113/gsecongeo.96.3.525.

U.S. Geological Survey (2019) Mineral Commodity Summaries 2019: https://www.usgs.gov/centers/nmic/mineral-commodity-summaries (accessed).

Vukmanovic, Z., Reddy, S.M., Godel, B., Barnes, S.J., Fiorentini, M.L., Barnes, S.J., and Kilburn, M.R., 2014, Relationship between microstructures and grain-scale trace element distribution in komatiite-hosted magmatic sulphide ores: Lithos, v. 184-187, p. 42-61, https://doi.org/10.1016/j.lithos.2013.10.037 (accessed 28 February 2019).

Wagner, T., and Monecke, T., 2005, Germanium-bearing colusite from the Waterloo volcanic-rock-hosted massive sulfide deposit, Australia: Crystal chemistry and formation of colusite-group minerals: Canadian Mineralogist, v. 43, p. 655-669, https://doi.org/10.2113/gscanmin.43.2.655.

Ye, L., Cook, N.J., Ciobanu, C.L., Yuping, L., Qian, Z., Tiegeng, L., Wei, G., Yulong, Y., and Danyushevskiy, L., 2011, Trace and minor elements in sphalerite from base metal deposits in South China: A LA-ICPMS study: Ore Geology Reviews, v. 39, p. 188-217, https://doi.org/10.1016/j.oregeorev.2011.03.001.

\section{FIGURE CAPTIONS}

Figure 1. (A) Map of Variscan massifs in Western Europe, and location of B. (B) Simplified geological map of the Pyrenean Axial Zone (PAZ) and location of main $\mathrm{Pb}-\mathrm{Zn}$ deposits (yellow stars, from Pouit [1985] and Bureau de Recherches Géologiques et Minières database [http://infoterre.brgm.fr] and Instituto Geológico y Minero de España 
Publisher: GSA

Journal: GEOL: Geology

DOI:10.1130/G46791.1

database [http://mapas.igme.es/Servicios/default.aspx]). Study area is highlighted with blue star. (C) Geological and structural map of the Arre deposit area. Pb-Zn ore is hosted in $\mathrm{N} 060^{\circ} \mathrm{E}-\mathrm{N} 080^{\circ} \mathrm{E}$ subvertical veins hosted in Lower Devonian marble calc-schist. Location of Figure $2 \mathrm{~A}$ is indicated.

Figure 2. (A) Outcrop photograph of Arre (Pyrenean Axial Zone, Pyrenees) Pb-Zn vein type. Note $\mathrm{S}_{2}$ cleavage in the host rock. Location of the studied sample (B) is indicated (modified from Cugerone et al., 2018b). (B) Photograph of ore. Sphalerite (Sph) appears light gray and is associated with quartz aggregate (Qtz) and schistose host rock. Location of the studied section (C) is indicated. (C) Plane-polarized (transmitted) light microphotograph of studied ore (150- $\mu \mathrm{m}$-thick section). Sphalerite presents color zonations (dark and light brown) and is crosscut by $\mathrm{S}_{2}$ cleavage. Location of Figure 4 is indicated. Sph—sphalerite, Qtz-quartz, $\mathrm{S}_{2}-\mathrm{S}_{2}$ regional cleavage plane.

Figure 3. Sphalerite microstructures and locations of Ge minerals in Arre (Pyrenean Axial Zone, Pyrenees) sample. (A) Plane-polarized (transmitted) light microphotograph of mineralized sample (30 $\mu \mathrm{m}$ thin section). Sph—sphalerite, Qtz-quartz, $\mathrm{S}_{2}-\mathrm{S}_{2}$ cleavage plane. (B) Locations of Ge minerals superimposed on sphalerite electron backscattered diffraction (EBSD) grain-size map (misorientation threshold to define grains is fixed at $20^{\circ}$ ). Sphalerite grains are distinguished into two groups as a function of their grain size. Smaller grains $(<100 \mu \mathrm{m})$ define aggregated bands parallel to $\mathrm{S}_{2}$ cleavage. Note that Ge minerals are mainly located in, or close to, these fine-grained bands. (C) Sphalerite EBSD inverse pole figure (IPF) map, plotted with respect to $x$-axis 
Publisher: GSA

Journal: GEOL: Geology

DOI: $10.1130 / \mathrm{G} 46791.1$

of projection sphere, showing internal plastic strain in coarse parent grains that are mantled by recrystallized smaller grains. $\mathrm{S}_{2}$ cleavage is marked by fine-grained recrystallization bands that crosscut parent sphalerite. Location of cumulative misorientation profile (E) is specified. (D) Histogram distribution and cumulative frequency curve of sphalerite grain size displaying two grain-size populations: coarse ( $>100 \mu \mathrm{m}$, brown) parent grains and small $(<100 \mu \mathrm{m}$, blue) recrystallized grains. Threshold is considered where cumulative frequency curve becomes subhorizontal. (E) Cumulative misorientation profile relative to start point acquired through single sphalerite parent grain, crosscut by fine-grained band of recrystallized grains. (F) Misorientation angle distribution histograms plotting neighbor-pair (correlated) and random-pair (uncorrelated) misorientations for sphalerite grains in studied area $\left(>2^{\circ}\right)$.

Figure 4. Ge concentration in sphalerite and locations of Ge minerals in Arre (Pyrenean Axial Zone, Pyrenees) sample. (A) Electron backscattered diffraction (EBSD) inverse pole figure (IPF) map, plotted with respect to $x$-axis of projection sphere. Note that $\mathrm{S}_{2}$ cleavage is marked by fine-grained recrystallization bands that crosscut parent sphalerite. (B) Ge distribution map from laser-induced breakdown spectroscopy (LIBS). Ge minerals are represented by higher Ge concentration (yellow areas). Patchy dark-brown domains correspond to higher Ge concentration ( $\sim 600 \mathrm{ppm} \mathrm{Ge})$ in parent sphalerite. Lighter domains (blue to light brown) indicate intermediate to low Ge concentrations (10-150 ppm Ge) in sphalerite. Recrystallized grains show lower Ge concentration (blue, $<100$ ppm Ge). Qtz-quartz. (C) Locations of Ge minerals superimposed on sphalerite EBSD grain-size map. Note the presence of Ge minerals in the finest sphalerite fraction 
Publisher: GSA

Journal: GEOL: Geology

DOI:10.1130/G46791.1

$(<100 \mu \mathrm{m})$ or in twin planes. Reflected plane-polarized light, close-up microphotograph shows brunogeierite $\left(\mathrm{GeFe}_{2} \mathrm{O}_{4}\right)$ crystal. (D) Ge versus $\mathrm{Cu}$ concentrations (expressed in $\mathrm{ppm}$ ) in sphalerites obtained from electron probe microanalyzer (EPMA) measurements, in dark, light, and recrystallized sphalerite from the Arre deposit (colored symbols) and other Pyrenean Axial Zone (PAZ) vein-type sphalerite (white symbols). Color code corresponds to that used in LIBS map in B. 


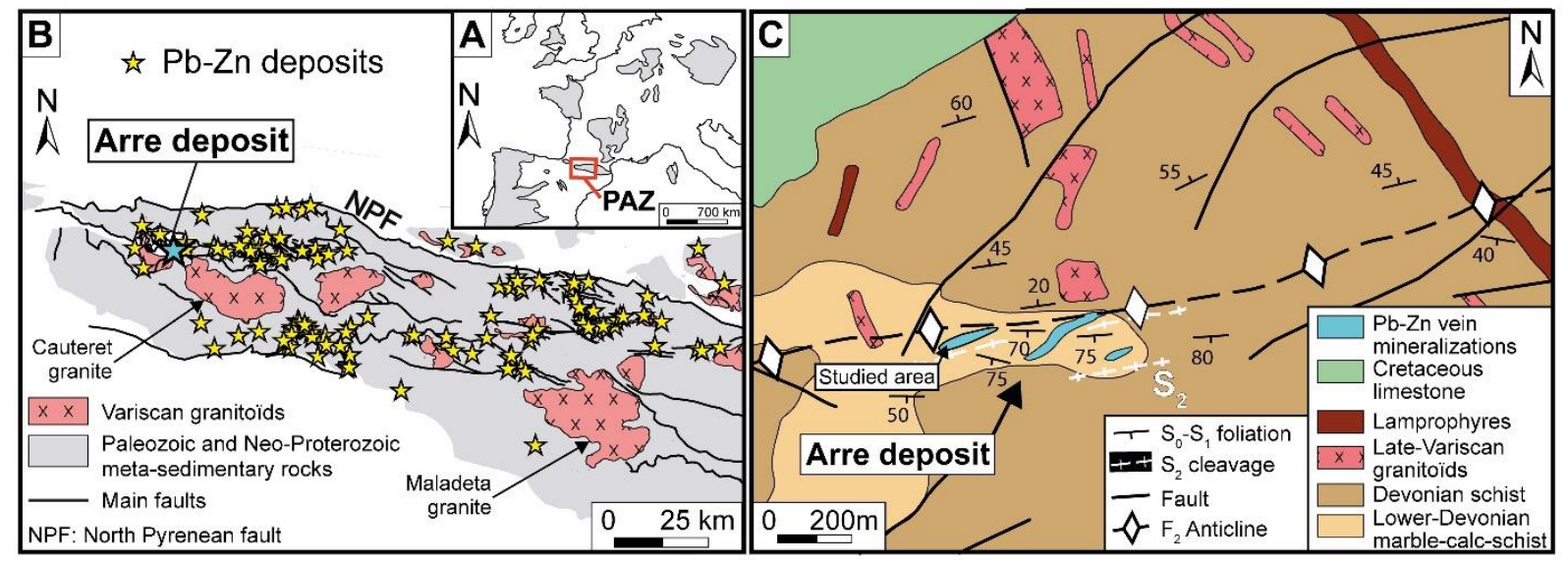

FIG. 1 

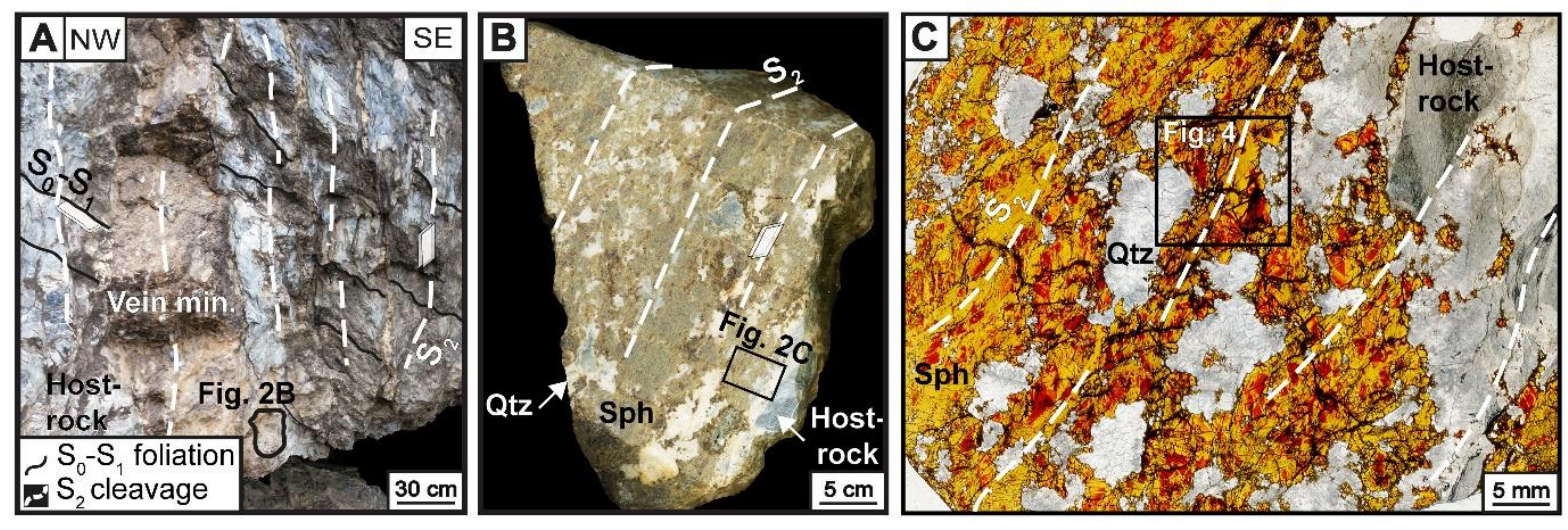

FIG. 2 

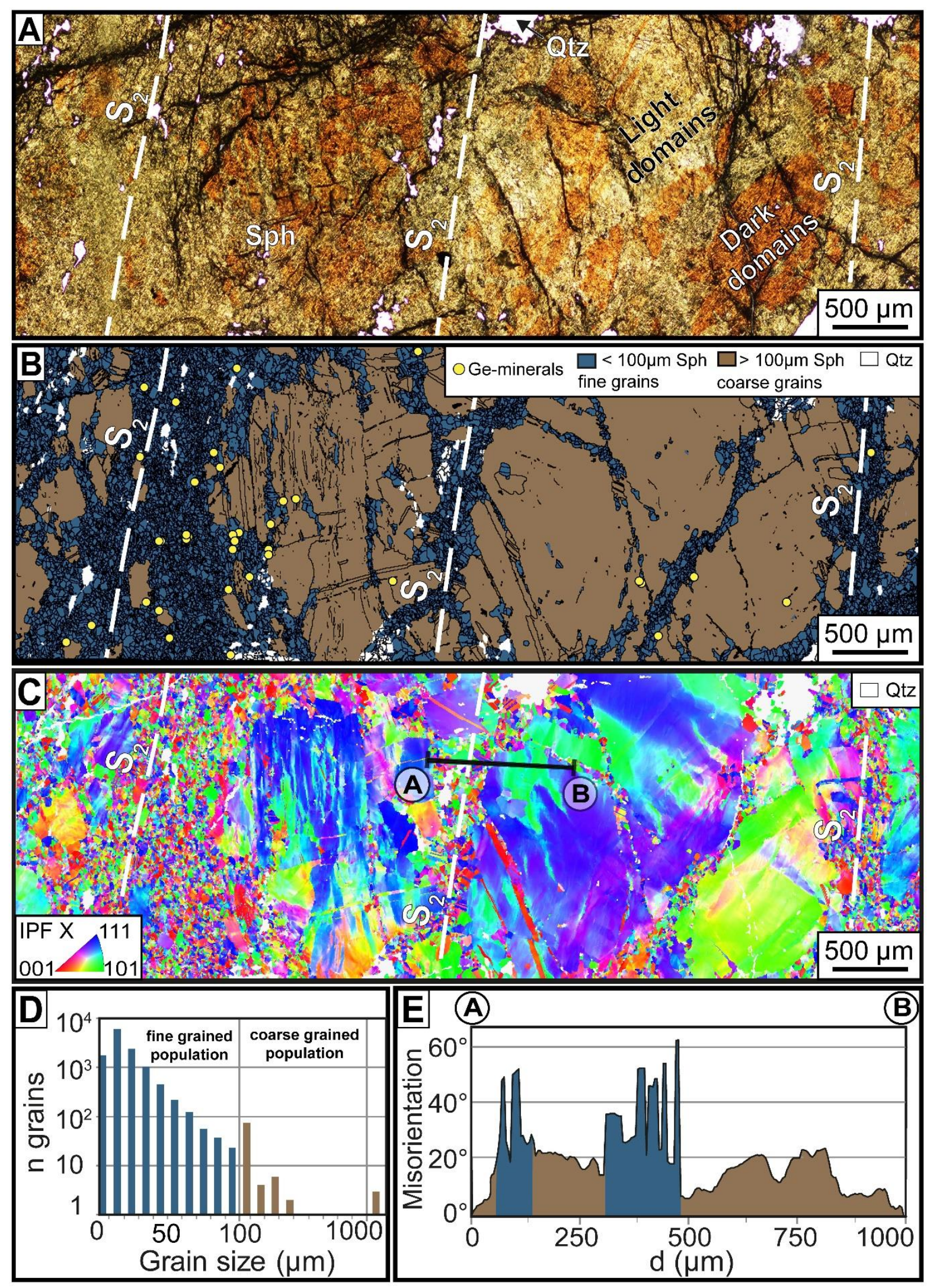

FIG. 3 

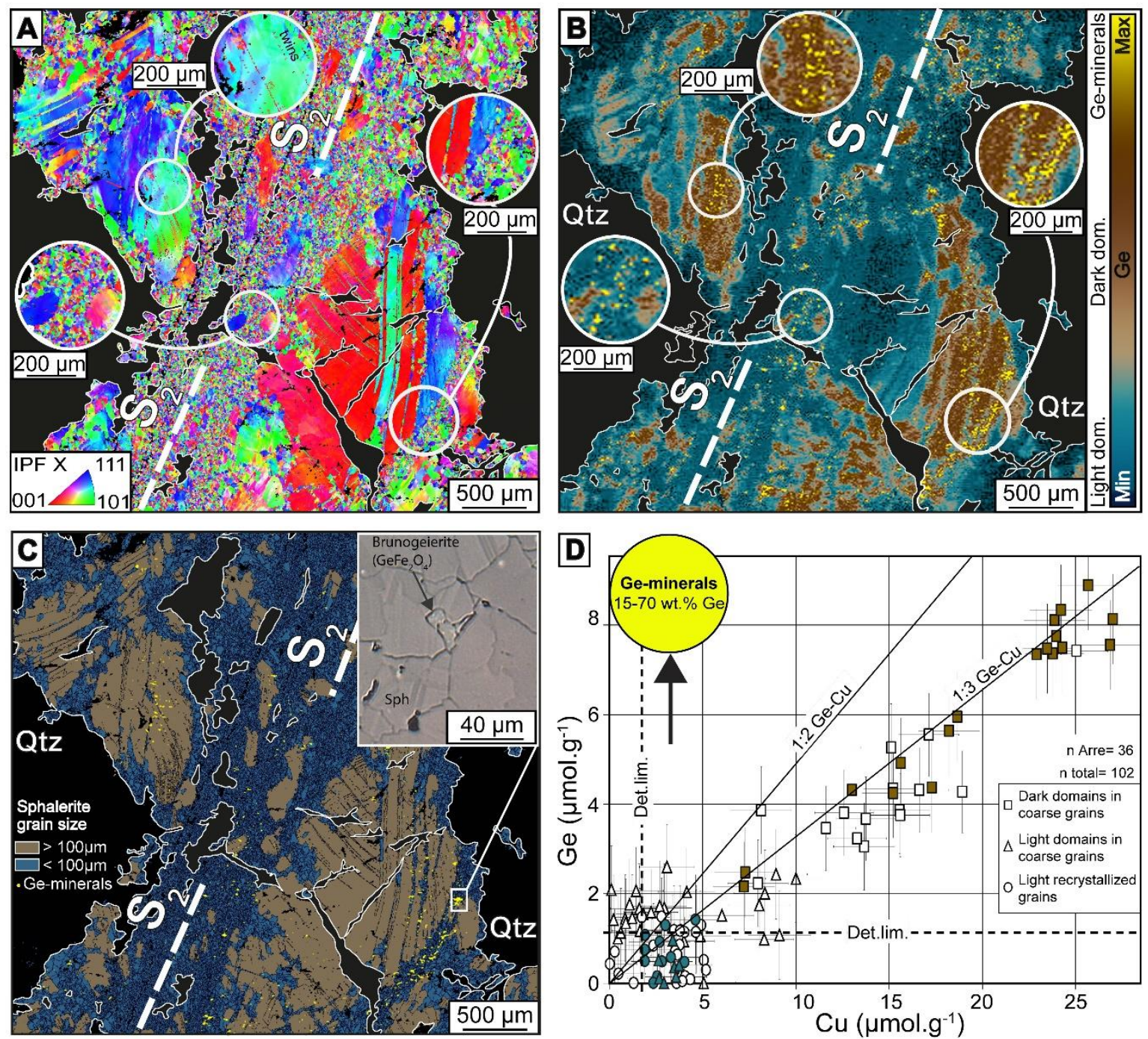

FIG. 4 